\title{
Tri-center Survey of Awareness of Infectious Diseases among Senior Dental Students in Riyadh
}

\author{
Dr. Syed Hammad Ahsan ${ }^{1}$, Hezekiah A. Mosadomi ${ }^{2}$, Tariq Alothman ${ }^{3}$, Mohammed Alenazi ${ }^{4}$, \\ Mohannad Abdullah Alowin ${ }^{5}$, Abdullah Alhumali ${ }^{6}$, Fahad ALShahrani ${ }^{7}$ \\ ${ }^{1}$ Lecturer, OMFS/DOS \\ ${ }^{2}$ Professor and Course Director \\ ${ }^{3,4,5,6,7}$ Students
}

\begin{abstract}
It is mandatory for dentists to enhance their knowledge regarding the nature, associated hazards and infection control guidelines of BBV diseases.[7] Inability to gain relevant knowledge will result in reluctance to treat BBV infected patients, as shown by a study in which dental students were reluctant in treating AIDS patients because of lack of confidence in managing such patients.[5] In addition to knowledge, two other important traits of a dentist which influence the implementation of infection control guidelines and the treatment provided to $B B V$ patients, are attitude and behavior of a dentist.
\end{abstract}

Keywords: viruses, awareness, infectious, diseases, HIV

\section{Introduction}

Blood borne viruses (BBV) are heterogeneous group of viruses which share a unique characteristic of transmission between hosts via blood. A dentist is morally and professionally obliged to treat dental patients infected by BBV. ${ }^{[1]}$ They comprise of blood-borne and other occupational microbial diseases that have a huge risk of transmission to dental health care workers and patients in everyday dental practice, such as, adenovirus, cytomegalovirus, epstein-barr virus, influenza virus and parainfluenza virus. ${ }^{[2]}$ Refusal to treat such patients can result in disciplinary action against the dentist in certain parts of the world. ${ }^{[3]}$ However, the practice of treating BBV infected patients is not a norm. BBV infected patients are usually denied treatment on the basis of their disease. ${ }^{[4]}$

Saudi Arabia (KSA) is not an exception in relevance to prevalence of BBV. HBsAg positivity in KSA has been shown to be around $8.3 \%$. ${ }^{[5]}$ Infectious diseases, such as $\mathrm{HIV}$, are one of the most complex health problems in the 21st century. ${ }^{[6]}$ The overall number of HIV positive Saudis by 2010 was reported to be $4019 .{ }^{[7]}$ These studies did not incorporate prevalence of $\mathrm{BBV}$ in foreign nationals residing in KSA, which would further increase the overall prevalence of such diseases. As, the number of such patients continue to increase, it is mandatory for dentists to enhance their knowledge regarding the nature, associated hazards and infection control guidelines of BBV diseases. ${ }^{[7]}$ Inability to gain relevant knowledge will result in reluctance to treat BBV infected patients, as shown by a study in which dental students were reluctant in treating AIDS patients because of lack of confidence in managing such patients. ${ }^{[5]}$ In addition to knowledge, two other important traits of a dentist which influence the implementation of infection control guidelines and the treatment provided to BBV patients, are attitude and behavior of a dentist. Attitude is defined as "a psychological tendency that is expressed by evaluating a particular entity with some degree of favor or disfavor". ${ }^{[8]}$ While, behavior is defined as "internally coordinated responses (actions or inactions) of whole living organisms (individuals or groups) to internal and/or external stimuli". ${ }^{[9]}$ It is pivotal to assess knowledge, attitude and behavior (KAB) of dentists towards BBV infected patients, so that, mandatory steps could be taken in the future to enhance the treatment quality of BBV infected patients and the confidence of dentist in managing such patients.

The awareness level of dentists towards infectious diseases is usually good but compliance to infection control protocols is globally suboptimal ${ }^{[10]}$ Few studies of such nature have been conducted in Saudi Arabia. A study assessed the implementation of infection control protocol in private sector. ${ }^{[11]}$ Another study assessed the awareness \& attitude of dentists towards Hepatitis B vaccination. ${ }^{[12]}$ Recently, a study assessed the knowledge \& attitude of male dental students towards AIDS patients. ${ }^{[5]} \mathrm{We}$ took into consideration the finding of these studies and widened the scope of our study, by inclusion of dentists of varying specialties, from both government and private health care sectors. A saudi based study stated that there should be an infection control manual \& educational program for dental sectors especially for private dental sectors ${ }^{[13]}$

As, dental students are to be the expected future dentists who will diagnose and treat numerous multi-cultural patients, thus, dental students awareness of infectious diseases must be assessed.

\section{Materials \& Methods}

\section{Study design}

It is a cross sectional survey based study.

\section{Sampling technique}

The study utilizes a two stage convenience sampling method. The first stage is characterized by selection of dental schools. The dental schools were selected on the basis of availability of final year dental students within that particular school.

\section{Volume 6 Issue 1, January 2017




\section{International Journal of Science and Research (IJSR) \\ ISSN (Online): 2319-7064}

Index Copernicus Value (2015): 78.96 | Impact Factor (2015): 6.391

Study site

The locations in which this study will be conducted include Riyadh Colleges of Dentistry \& Pharmacy located in King Fahad road and exit 8, King Saud University located in exist 2 and King Saud Bin Abdulaziz University for Health Sciences located in KashmAlaan road. All of these dental schools are located in the capital city of Saudi Arabia (Riyadh). The second stage is characterized by selection of subjects of the study.

\section{Study subjects}

The subjects will be final year dental students.

\section{Sample size}

The sample size will be 300 . The sample size is based on the cumulative number of final year dental students available in these dental schools.

\section{Data collection method}

The subjects will be provided an online self-prepared, structured questionnaire which comprises of sections relevant to "knowledge of infectious diseases", "knowledge of mode of transmission of infectious diseases", "knowledge of clinical features of infectious diseases" and "knowledge and behavior towards infection control guidelines of infectious diseases". On completion, the questionnaire will be submitted online.

\section{Statistical analysis}

The data will be transferred to SPSS version 16 and later. Frequency distribution and multiple logical regression analysis via SPSS version 16 will be utilized for statistical analysis of the data.

\section{Result}

\begin{tabular}{|l|c|c|c|c|c|}
\hline \multicolumn{5}{|c|}{ College } \\
\hline \multicolumn{2}{|c|}{} & Frequency & Percent & Valid Percent & $\begin{array}{c}\text { Cumulative } \\
\text { Percent }\end{array}$ \\
\hline Valid & RCsDP & 130 & 100.0 & 100.0 & 100.0 \\
\hline
\end{tabular}

\begin{tabular}{|c|c|c|c|c|c|}
\hline \multicolumn{9}{|c|}{ AttendSymp } \\
\hline \multicolumn{2}{|c|}{} & Frequency & Percent & Valid Percent & $\begin{array}{c}\text { Cumulative } \\
\text { Percent }\end{array}$ \\
\hline \multirow{4}{*}{\begin{tabular}{l} 
Valid \\
\cline { 2 - 6 }
\end{tabular}} & no & 69 & 53.1 & 53.1 & 53.1 \\
\cline { 2 - 6 } & not sure & 15 & 11.5 & 11.5 & 64.6 \\
\cline { 2 - 6 } & yes & 46 & 35.4 & 35.4 & 100.0 \\
\cline { 2 - 6 } & Total & 130 & 100.0 & 100.0 & \\
\hline
\end{tabular}

\begin{tabular}{|c|c|c|c|c|c|}
\hline \multicolumn{5}{|c|}{ Gender } \\
\hline \multicolumn{2}{|c|}{} & Frequency & Percent & Valid Percent & $\begin{array}{c}\text { Cumulative } \\
\text { Percent }\end{array}$ \\
\hline \multirow{2}{*}{ Valid } & Female & 72 & 55.4 & 55.4 & 55.4 \\
\cline { 2 - 6 } & Male & 58 & 44.6 & 44.6 & 100.0 \\
\hline
\end{tabular}

\begin{tabular}{|c|c|c|c|c|c|}
\hline & Total & 130 & 100.0 & 100.0 & \\
\hline \multicolumn{6}{|c|}{ EducationOfInfDisease } \\
\hline & & Frequency & Percent & Valid Percent & $\begin{array}{c}\text { Cumulative } \\
\text { Percent }\end{array}$ \\
\hline \multirow{4}{*}{ Valid } & no & 18 & 13.8 & 13.8 & 13.8 \\
\hline & not sure & 6 & 4.6 & 4.6 & 18.5 \\
\hline & yes & 106 & 81.5 & 81.5 & 100.0 \\
\hline & Total & 130 & 100.0 & 100.0 & \\
\hline
\end{tabular}

\begin{tabular}{|c|c|c|c|c|c|}
\hline \multicolumn{7}{|c|}{ EducationWasSufficient } \\
\hline \multicolumn{2}{|c|}{} & Frequency & Percent & $\begin{array}{c}\text { Valid } \\
\text { Percent }\end{array}$ & $\begin{array}{c}\text { Cumulative } \\
\text { Percent }\end{array}$ \\
\hline \multirow{4}{*}{ Valid } & & 2 & 1.5 & 1.5 & 1.5 \\
\cline { 2 - 6 } & no & 41 & 31.5 & 31.5 & 33.1 \\
\cline { 2 - 6 } & not sure & 27 & 20.8 & 20.8 & 53.8 \\
\cline { 2 - 6 } & yes & 60 & 46.2 & 46.2 & 100.0 \\
\cline { 2 - 6 } & Total & 130 & 100.0 & 100.0 & \\
\hline
\end{tabular}

None of the students could accurately guess all the oral lesions in AIDS, namely, Kaposi's Sarcoma, Oral Candidiasis, Acute ulcerative gingivitis, Hairy Leukoplakia, Herpes Simplex infection, Xerostomia, Cytomegalovirus Infection

14 students $(10.8 \%)$ rightly guessed oral manifestation of $\mathrm{TB}$ in the form of an ulcer

None of the students correctly diagnosed all the oral lesions of syphilis, namely, gumma, chancre, maculopapular rash and leukoplakia

None of the students correctly diagnosed all the oral lesions of HSV, namely, ulcer, vesicle, Gingivostomatitis and Labialis

Two students $(1.5 \%)$ rightly stated all the oral lesions of $\mathrm{HZV}$, namely, ulcer, vesicle, neuralgia

Only one student $(0.7 \%)$ stated that HBV can transmit through saliva, sputum and blood

Only one student $(0.7 \%)$ stated that $\mathrm{HCV}$ can transmit through saliva, sputum and blood

Only one student $(0.7 \%)$ stated that HDV can transmit through saliva, sputum and blood

Fourteen students $(10.8 \%)$ stated that HIV spreads by direct contact and blood, while, one student $(0.7 \%)$ stated that HIV spreads through saliva, sputum and blood

Only twenty seven students $\mathbf{( 2 0 . 8 \% )}$ stated that MERS spreads through aerosol droplets 


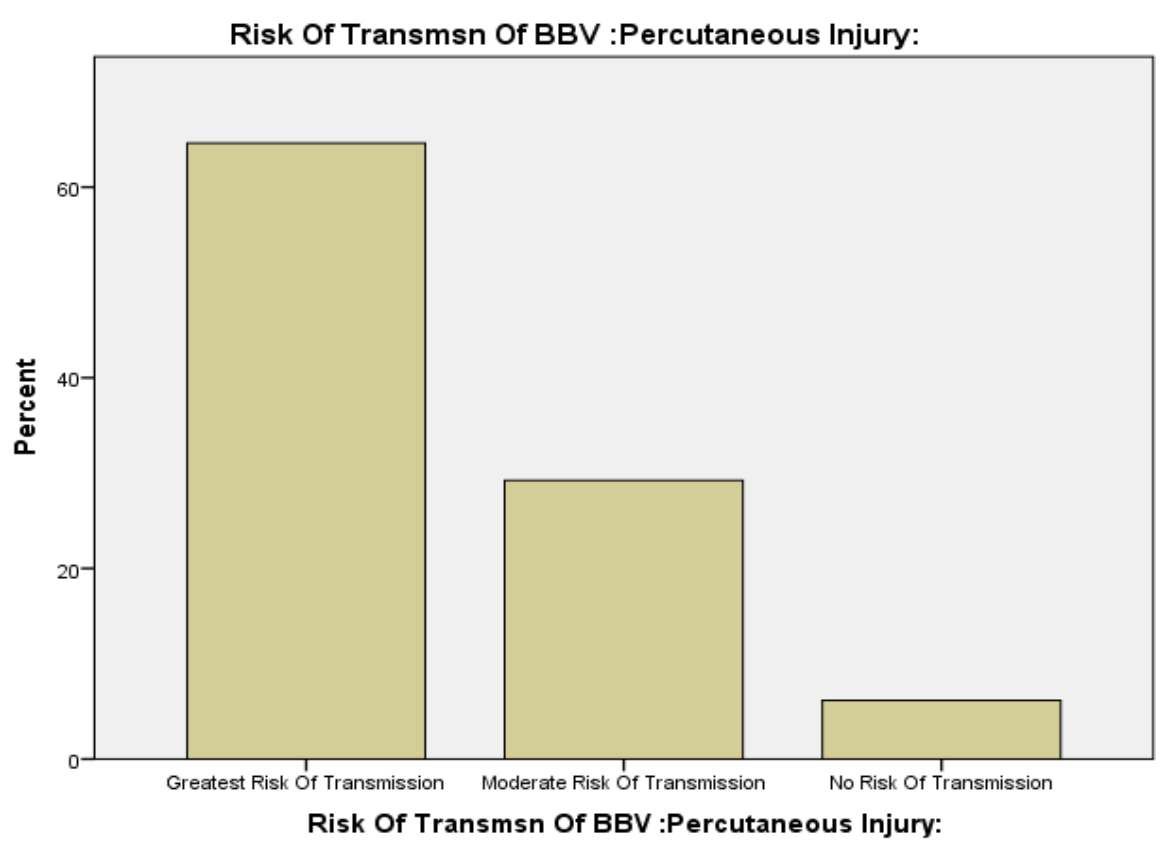

Note: 84 students $(64.6 \%)$ stated that Percutaneous injury has greatest Risk Of Transmitting BBV infection, which is true

\begin{tabular}{|c|c|c|c|c|c|}
\hline \multicolumn{6}{|c|}{ Which BBV Greatst Risk } \\
\hline & & Frequency & Percent & \begin{tabular}{|c|} 
Valid \\
Percent
\end{tabular} & $\begin{array}{c}\text { Cumulative } \\
\text { Percent }\end{array}$ \\
\hline \multirow{4}{*}{ Valid } & Hepatitis B Virus & 55 & 42.3 & 42.3 & 42.3 \\
\hline & Hepatitis C Virus & 28 & 21.5 & 21.5 & 63.8 \\
\hline & HIV & 47 & 36.2 & 36.2 & 100.0 \\
\hline & Total & 130 & 100.0 & 100.0 & \\
\hline
\end{tabular}

\begin{tabular}{|c|c|c|c|c|c|}
\hline \multicolumn{6}{|c|}{ HBV Immunization } \\
\hline \multicolumn{1}{|c|}{} & Frequency & Percent & $\begin{array}{c}\text { Valid } \\
\text { Percent }\end{array}$ & $\begin{array}{c}\text { Cumulative } \\
\text { Percent }\end{array}$ \\
\hline \multirow{5}{*}{ Valid } & $\begin{array}{c}\text { No Vaccination } \\
\text { Available }\end{array}$ & 14 & 10.8 & 10.8 & 13.1 \\
\cline { 2 - 6 } & $\begin{array}{c}\text { Vaccination } \\
\text { Available }\end{array}$ & 113 & 86.9 & 86.9 & 100.0 \\
\cline { 2 - 6 } & Total & 130 & 100.0 & 100.0 & \\
\hline
\end{tabular}

\begin{tabular}{|c|c|c|c|c|c|}
\hline \multicolumn{9}{|c|}{ HCV Immunization } \\
\hline \multicolumn{3}{|c|}{} & Frequency & Percent & Valid \\
Percent & Cumulative & Percent \\
\hline \multirow{4}{*}{ Valid } & $\begin{array}{c}\text { No Vaccination } \\
\text { Available }\end{array}$ & 52 & 5.4 & 5.4 & 5.4 \\
\cline { 2 - 6 } & Vaccination Available & 71 & 54.6 & 54.6 & 100.0 \\
\cline { 2 - 6 } & Total & 130 & 100.0 & 100.0 & \\
\hline
\end{tabular}

NOTE: Only 27 (20.8\%) students knew that interferon is used for management of HBV infection

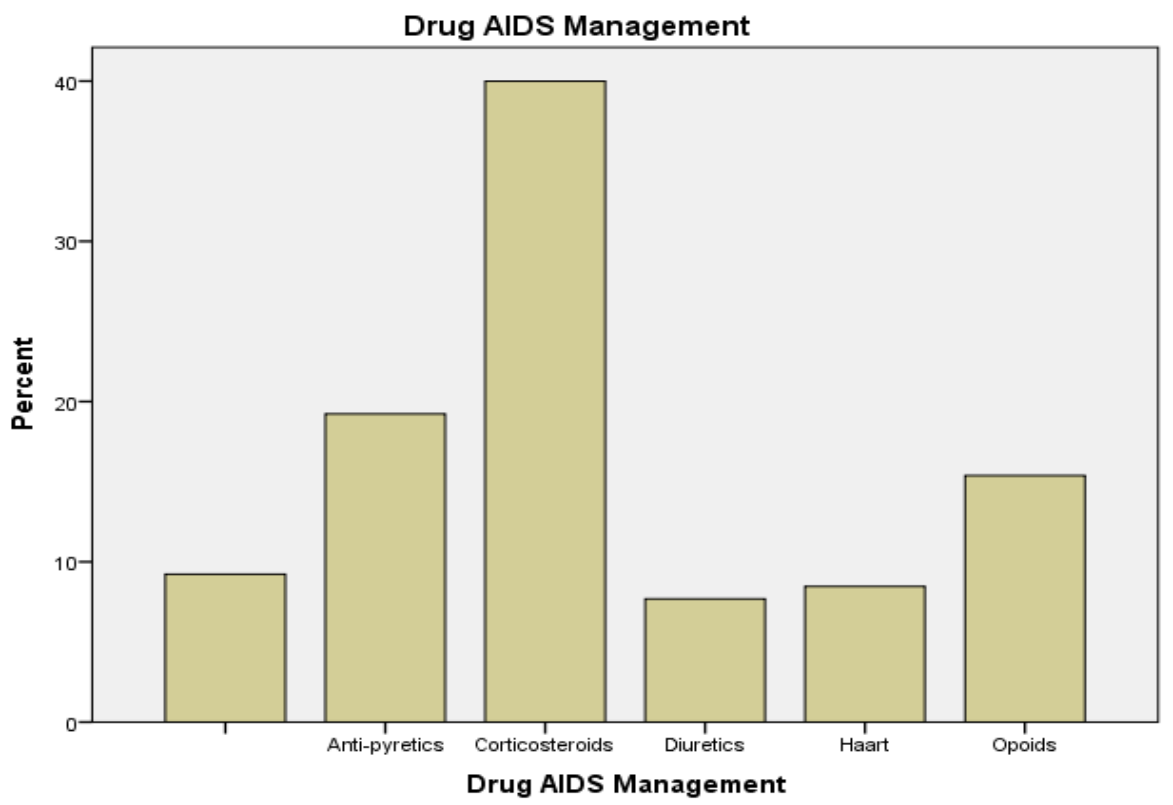

NOTE: Only 11 students $(8.5 \%)$ knew that HAART are class of drugs used for management of AIDS

Volume 6 Issue 1, January 2017

www.ijsr.net

Licensed Under Creative Commons Attribution CC BY 
International Journal of Science and Research (IJSR)

ISSN (Online): 2319-7064

Index Copernicus Value (2015): 78.96 | Impact Factor (2015): 6.391

\begin{tabular}{|c|c|c|c|c|c|}
\hline \multicolumn{6}{|c|}{ You Got HBV Vacine } \\
\hline \multicolumn{2}{|c|}{} & Frequency & Percent & $\begin{array}{c}\text { Valid } \\
\text { Percent }\end{array}$ & $\begin{array}{c}\text { Cumulative } \\
\text { Percent }\end{array}$ \\
\hline \multirow{4}{*}{ Valid } & & 1 & .8 & .8 & .8 \\
\cline { 2 - 6 } & no & $\mathbf{3 9}$ & $\mathbf{3 0 . 0}$ & 30.0 & 30.8 \\
\cline { 2 - 6 } & yes & 90 & 69.2 & 69.2 & 100.0 \\
\cline { 2 - 6 } & Total & 130 & 100.0 & 100.0 & \\
\hline
\end{tabular}

NOTE: 39 students (30\%) didn't get HBV vaccination and they are practicing dentistry?

$51(39.2 \%)$ students were concerned about increase in personal risk due to treating BBV patients
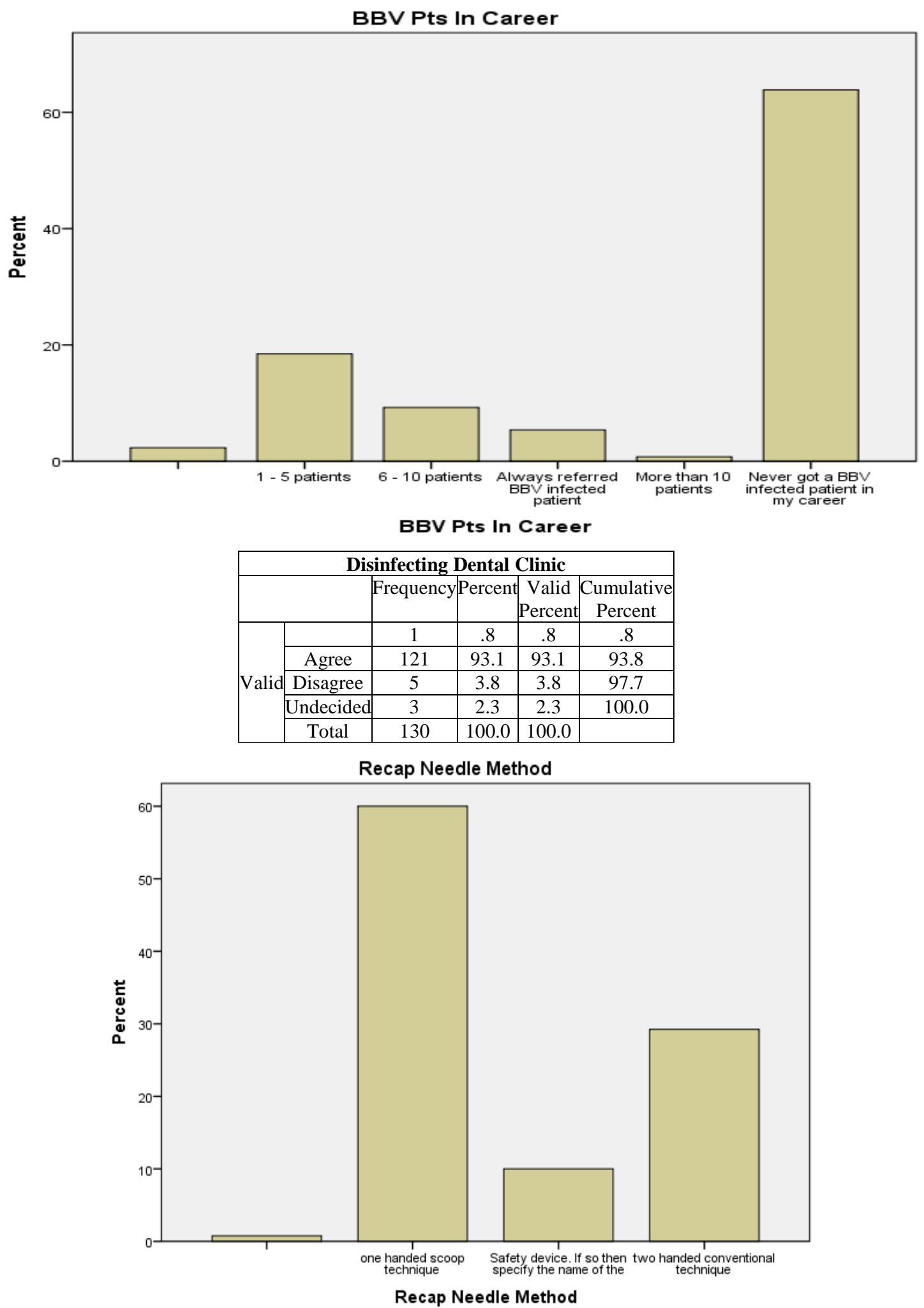

NOTE: 78 students $(60 \%)$ practice one handed scoop technique when they recap needles, which is a good thing. While, 38 (29.2\%) use the two handed technique

Volume 6 Issue 1, January 2017

www.ijsr.net

Licensed Under Creative Commons Attribution CC BY 


\section{International Journal of Science and Research (IJSR) \\ ISSN (Online): 2319-7064}

Index Copernicus Value (2015): 78.96 | Impact Factor (2015): 6.391

\section{CHI SQUARE TEST RESULTS}

Gender * Transmission Of HCV

\begin{tabular}{|c|c|c|c|}
\hline \multicolumn{5}{|c|}{ Chi-Square Tests } \\
\hline & Value & df & Asymp. Sig. (2-sided) \\
\hline Pearson Chi-Square & $55.465^{\text {a }}$ & 30 & .003 \\
\hline Likelihood Ratio & 71.202 & 30 & .000 \\
\hline N of Valid Cases & 130 & & \\
\hline $\begin{array}{c}\text { a. 58 cells (93.5\%) have expected count less than 5. The } \\
\text { minimum expected count is .45.(assumption has been violated. } \\
\text { A fisher's exact test can be performed here) }\end{array}$ \\
\hline
\end{tabular}

NOTE: A significant proportion of female students stated that HCV transmits through blood and saliva while most male students stated that blood is the only route of transmission

\section{Gender * Transmission Of MERS}

\begin{tabular}{|c|c|c|c|}
\hline \multicolumn{4}{|c|}{ Chi-Square Tests } \\
\hline & Value & df & Asymp. Sig. (2-sided) \\
\hline Pearson Chi-Square & $39.138^{\text {a }}$ & 23 & .019 \\
\hline Likelihood Ratio & 49.607 & 23 & .001 \\
\hline N of Valid Cases & 130 & & \\
\hline $\begin{array}{c}\text { a. 39 cells (81.3\%) have expected count less than 5. The } \\
\text { minimum expected count is .45.(assumption has been } \\
\text { violated. A fisher's exact test can be performed here) }\end{array}$ \\
\hline
\end{tabular}

NOTE: Most of the female students stated that MERS transmits by aerosol droplets while only few male students answered the same

\section{Gender * Risk Of Transmsn Of BBV :Percutaneous Injury:}

\begin{tabular}{|c|c|c|c|}
\hline \multicolumn{4}{|c|}{ Chi-Square Tests } \\
\hline & Value & df & Asymp. Sig. (2-sided) \\
\hline Pearson Chi-Square & $6.754^{\mathrm{a}}$ & 2 & .034 \\
\hline Likelihood Ratio & 6.834 & 2 & .033 \\
\hline N of Valid Cases & 130 & & \\
\hline & a. 2 cells (33.3\%) have expected count less than 5. The \\
minimum expected count is 3.57.(assumption has been \\
violated. A fisher's exact test can be performed here)
\end{tabular}

\begin{tabular}{|c|c|c|c|}
\hline \multicolumn{4}{|c|}{ Symmetric Measures } \\
\hline \multirow{2}{|c|}{ Nominal by Nominal } & Phi & .228 & .034 \\
\cline { 2 - 4 } & Cramer's V & .228 & .034 \\
\hline \multicolumn{2}{|c|}{ N of Valid Cases } & 130 & \\
\hline
\end{tabular}

Anything above .157 is considered to have a good impact

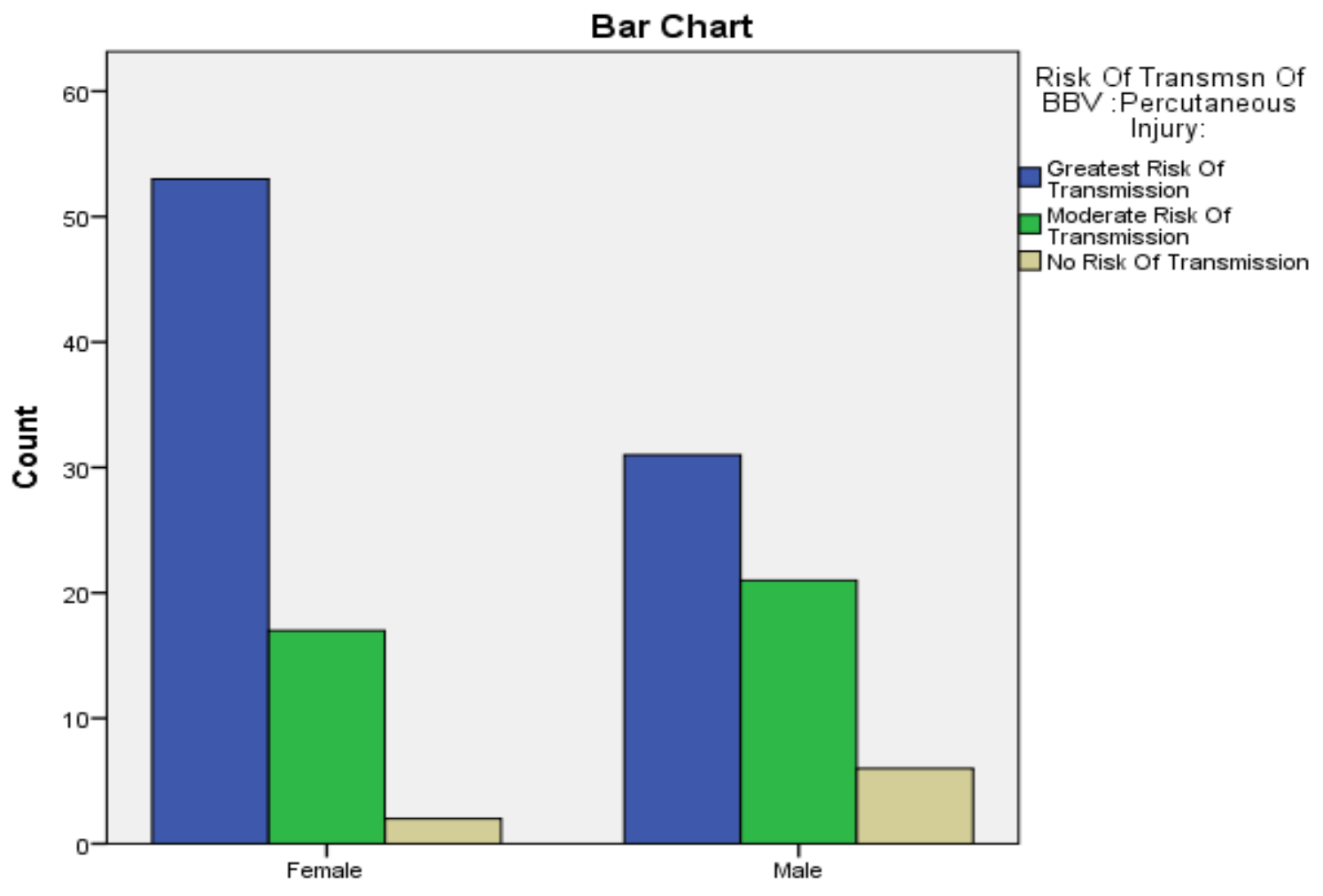

Gender

\begin{tabular}{|c|c|c|c|}
\hline \multicolumn{4}{|c|}{ Gender * You Got HBV Vaccine } \\
\hline \multicolumn{4}{|c|}{ Chi-Square Tests } \\
\hline & Value & $\mathrm{df}$ & Asymp. Sig. (2-sided) \\
\hline Pearson Chi-Square & $9.100^{\mathrm{a}}$ & 2 & .011 \\
\hline Likelihood Ratio & 9.499 & 2 & .009 \\
\hline $\mathrm{N}$ of Valid Cases & 130 & & \\
\hline $\begin{array}{r}\text { a. } 2 \text { cells }(33.3 \%) \text { h } \\
\text { minimum expected cou } \\
\text { A fisher's exa }\end{array}$ & $\begin{array}{l}\text { ve expec } \\
t \text { is } .45 . \\
t \text { test cal }\end{array}$ & & $\begin{array}{l}\text { unt less than } 5 \text {. The } \\
\text { ttion has been violated } \\
\text { rformed here) }\end{array}$ \\
\hline
\end{tabular}

\begin{tabular}{|c|c|c|c|}
\hline \multicolumn{4}{|c|}{ Symmetric Measures } \\
\hline \multirow{2}{|c|}{} & Value & Approx. Sig. \\
\hline \multirow{2}{*}{ Nominal by Nominal } & Phi & .265 & .011 \\
\cline { 2 - 4 } & Cramer's V & .265 & .011 \\
\hline \multicolumn{2}{|c|}{ N of Valid Cases } & 130 & \\
\hline
\end{tabular}

Anything above .157 is considered to have a good impact

\section{Volume 6 Issue 1, January 2017 www.ijsr.net}




\section{International Journal of Science and Research (IJSR) \\ ISSN (Online): 2319-7064}

Index Copernicus Value (2015): 78.96 | Impact Factor (2015): 6.391

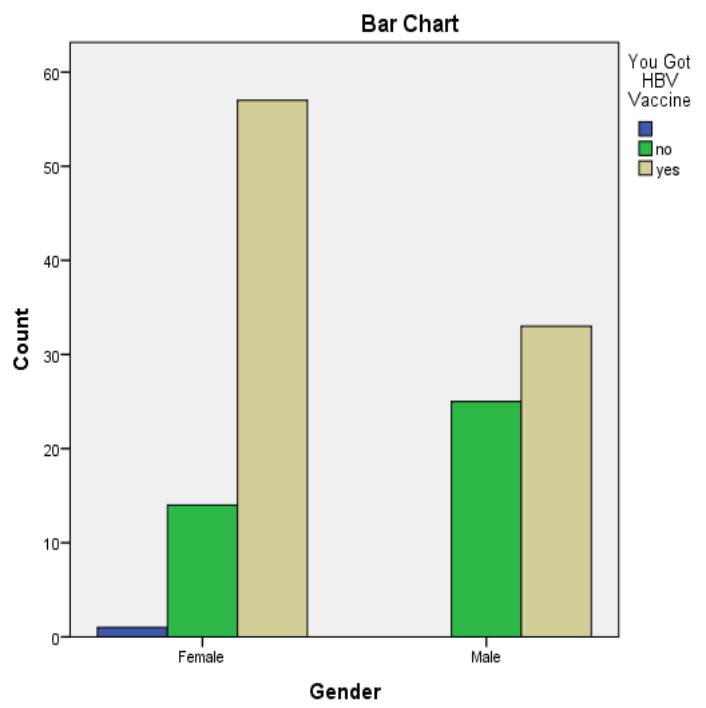

Gender * Drug HBV Management

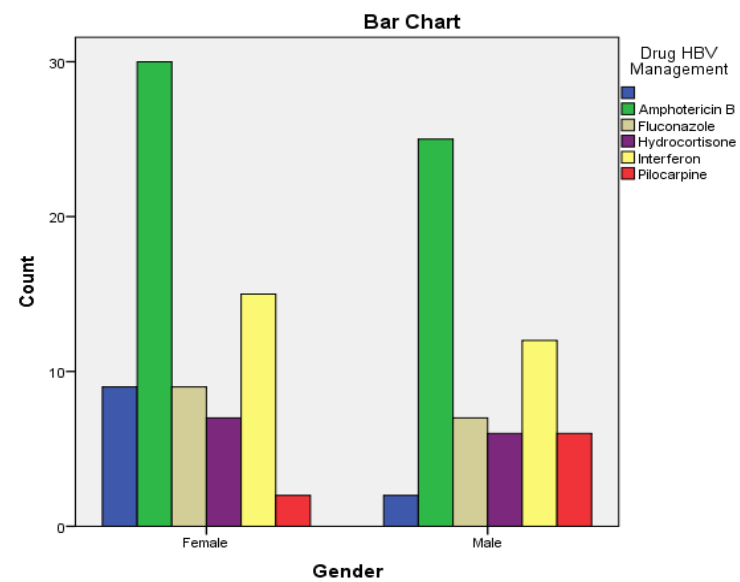

NOTE: No statistically significant difference but interesting specially the green highlighted bar which shows Amphotericin B which is wrong

Gender * Drug AIDS Management

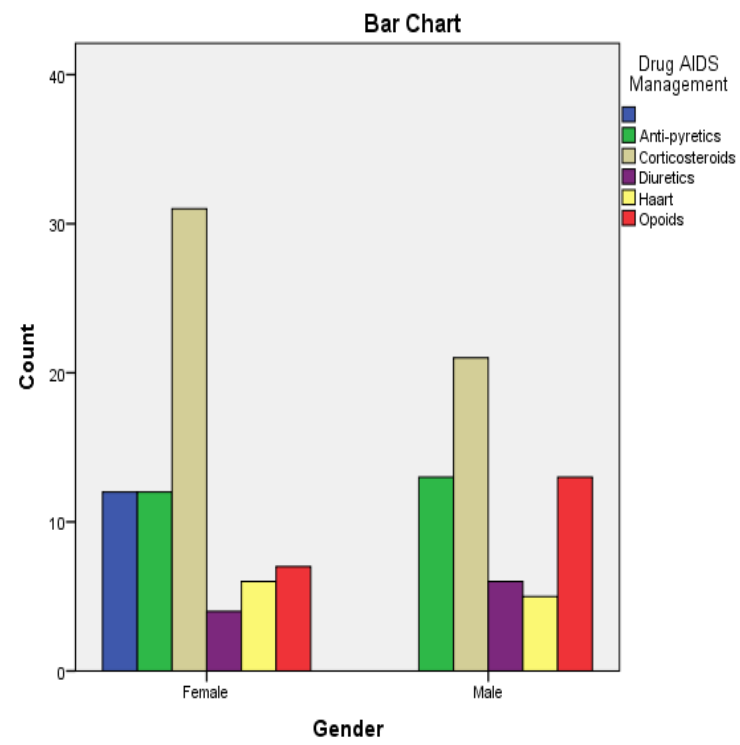

NOTE: No statistically significant difference but interesting specially the brown highlighted bar which shows Corticosteroids which is wrong

\section{References}

[1] Canadian Dental Association. Statement on the ethical and legal considerations of treating patients with infectious diseases. J Can Dent Assoc. 1988; 54: 385

[2] Szymanska J: Microbiological risk factors in dentistry. Current status of knowledge. Ann Agric Environ Med 2005, 12, 157-163. Panov V, Krasteva A. Oral health in patients with liver diseases. J of IMAB. 2011; 17(2):140-142. [CrossRef]

[3] American Dental Association. ADA takes action on two HIV fronts. ADA News Releases. June 1996

[4] McCarthy M, Koval J, MacDonald J. Factors associated with refusal to treat HIV infected patients: The results of a national survey of dentist n Canada. Am J Public Health 1999; 89:541-545

[5] Awad S. Alsamghan. Knowledge and attitude of male dental students toward HIV/AIDS in King Khalid University, Saudi Arabia. International Journal of Public Health and Epidemiology. Oct 2012; Vol. 1 (1), pp. 001-008

[6] Alothman AF, Muhajer K, Balkhy H. Prevalence of HIV-infection in Saudi Arabia. BMC Proceedings. 2011; 5: 252

[7] Ungan M, Yaman H (2003) AIDS knowledge and educational needs of technical university students in Turkey. Patient EducCouns 51: 163-167.

[8] Darling M, Arendorf T, Samaranayake LP. Oral care of HIV-infected patients: the knowledge and atti-tudes of South African dentists. J. Dent. Assoc. S. Afr., 1992, 47(9): 399-402.

[9] Eagly, A. H., \&Chaiken, S. The psychology of attitudes. Harcourt Brace Jovanovich College Publisher. 1993

[10]Levitis, D.A., Lidicker, W.Z., and Freund, G.. Behavioural biologists do not agree on what constitutes behaviour. Animal Behaviour; 2009, 78, 103-110

[11] Al-Maweri SA, Tarakji B, Shugaa-Addin B, Al-Shamiri HM, Alaizari NA, AlMasri O. Infection con- trol: Knowledge and compliance among Saudi undergraduate dental stu- dents. GMS Hyg Infect Control. 2015 Jul 1;10:Doc10. [PubMed] [CrossRef].

[12] Abdullah AR, Ashry GM. Infection control in the private dental sector in Riyadh. Ann Saudi Med; 2002, 292(1-2):13-17.

[13] Paul T, Maktabi A, Almas K, Saeed S. Hepatitis B awareness and attitudes amongst dental health care workers in Riyadh, Saudi Arabia. Odontostomatol Trop. 1999 Jun; 22(86):9-12

[14] Abdullah AR, Ashry GM (2002) Infection control in the private dental sector in Riyadh. Ann Saudi Med; 22(12):13-17.

[15]M. L. Crossley. An investigation of dentist's knowledge, attitudes and practices towards HIV+ and patients with other blood-borne viruses in South Cheshire, UK. British Dental Journal. June 26 2004; Volume 196 No. 12

[16] Updated CDC Recommendations for the Management of Hepatitis B Virus-Infected Health-Care Providers and Students. MMWR / July 6, 2012 / Vol. 61 / No. 